\title{
PENGARUH GAYA KEPEMIMPINAN KEPALA KELURAHAN DUAMPANUA KECAMATAN BARANTI KABUPATEN SIDRAP TERHADAP KINERJA PEMBANGUNAN
}

\author{
Nasriah Akil*) \\ Dosen STIM LPI Makassar
}

\begin{abstract}
Abstrak
Penelitian ini bertujuan untuk mengetahui pengaruh gaya kepemimpinan dan factor-factor yang mempengaruhi gaya kemimpiminan kepala Kelurahan Duampanua dalam melaksanakan Pembangunan dan manajemen pemerintahan. Metode penelitian yang digunakan adalah kualitatif deskriftif dengan menelaah pengaruhi implementasi kepemimpinan kepala kelurahan dengan wawancara mendalam melalui kuisioner. Hasil penelitian menanujukkan bahwa gaya kepemimpinan yang diterapkan oleh kepala kelurahan Duampanua Kecamatan Baranti Kabupaten Sidrap yaitu gaya kepemimpinan demokratif dan disusul dengan gaya patenalistik. Factor pendukung utama yaitu tingkat pendidikan, disusul kepribadian dan motovasi kerja.
\end{abstract}

Kata Kunci :Gaya Kepemimpinan, Kelurahan dan Kinerja Pembangunan

\begin{abstract}
This study aims to determine the influence of leadership style and factors that influence the leadership style of the Duampanua Urban Village chief in carrying out Government development and management.The research method used is descriptive qualitative by examining the influence of the implementation of the leadership of the village chief with indepth interviews through questionnaires. The results of the study showed that the leadership style adopted by the chief of Duampanua village, Baranti District, Sidrap Regency was democratic leadership style and followed by patenalistic style. The main supporting factors are the level of education, followed by personality and work motivation.
\end{abstract}

Keywords: Leadership Style, Village and Development Performance.

\section{PENDAHULUAN}

Pembangunan daerah sebagai bagian integral dari pembangunan nasional dilaksanakan berdasarkan prinsip otonomi daerah dan pengaturan sumber daya nasional yang memberikan kesempatan bagi peningkatan demokrasi dan kinerja daerah untuk meningkatkan kesejahteraan masyarakat menuju masyarakat madani yang bebas korupsi, kolusi dan nepotisme.Pemerintah Desa/Kelurahan sebagai aparat pemerintah terdepan dan berhubungan langsung dengan masyarakat,harus berupaya semaksimal mungkin untuk memberikan pelayanan kepada masyarakat sehingga pelayanan betul-betul dapat memuaskan dalam melayani masyarakat, sehingga pemerintah Desa/Kelurahan di tuntut untuk lebih meningkatkan profesionalisme didalam menyelenggarakan urusan pemerintahan di Desa/Kelurahan.

Pada suatu daerah sukses dan tidaknya bergantung pada optimalnya sumber dan efisiennya penggunaan dana. Sumber dana untuk penyelenggaraan suatu pemerintah daerah membutuhkan suatu ketelitian. Masyarakat dewasa ini sangat tinggi tingkat emosional dan egoisnya.

Bagi suatu organisasi, kegiatan manajemen merupakan suatu hal yang 
penting karena menyangkut masalah penggunaan tenaga kerja manusia (pegawai) untuk mencapai tujuan yang telah ditetapkan dalam organisasi yang bersangkutan. Kegiatan manajemen Lurah merupakan kegiatan yang dilakukan oleh Lurah/manajer berkenaan dengan perencanaan, pengorganisasian, penggerakan dan pengawasansejalan dengan azaz manajemen GR. Terry, (1970). Sehingga optimalnya kegiatan manajemen oleh kepala kantor mempengaruhi produktivitas kerja. Kemampuan kerja dari karyawan (pegawai) itu sendiri berpengaruh terhadap produktivitas kerja karyawan. Kemampuan kerja pegawai yang dapat diketahui melalui tingkat pengetahuan pegawai melalui latar belakang pendidikan, tingkat ketrampilan pegawai dan sikap mental serta kesehatan pegawai mempunyai pengaruh terhadap peningkatan produktivitas kerja pegawai di Kelurahan.

Manusia adalah salah satu dimensi dalam organisasi yang amat penting merupakan salah satu faktor dan pendukung organisasi. Tidak produktifnya pegawai kelurahan dipengaruhi oleh rendahnya produktivitas kerja pegawai. Rendahnya produktivitas kerja pegawai kelurahan dipengaruhi oleh berbagai faktor. Kantor Kelurahan sebagai kantor instansi pemerintahan terkecil, faktor manusia merupakan sumber terpenting, jika manusia dalam organisasi itu mempunyai kemauan kerja, kemampuan dan ketrampilan kerja ke arah tercapainya tujuan organisasi.

$$
\text { Produktifnya sumberdaya }
$$

manusia aparat desa dan kelurahan serta aparat sipil negara dalam artian efektif dalam pencapaian hasil dan efisien dalam penggunaan sumber daya. Namun demikian, kiranya dapat dipahami bahwa seseorang yang mampu dan terampil bekerja belum tentu produktif sekiranya ia tidak memiliki kemampuan kerja dan ini sukar teratasi(Siagian, Sondang P., 1997),. Begitu pula orang yang memiliki kemauan kerja saja belum tentu punya kemampuan dan keterampilan.

Hal ini akan lebih mudah diatasi jika orang yang memimpin mereka mampu mengarahkan dengan baik dan ini menjadi tanggung jawab dari kepala kantor (manajemen). Pemimpin tidak hanya mengarahkan saja melainkan dia diharapkan mampu melaksanakan fungsi - fungsi manajemen lainnyaHandayaningrat, Suwarno. (2003).Dari uraian tersebut dapat diketahui bahwa faktor - faktor seperti kemampuan kerja pegawai dan kemampuan manajemen Lurah merupakan faktor yang mempengaruhi produktivitas kerja pegawai Kantor Kelurahan. Berdasarkan dari asumsi asumsi di atas maka pada penelitian ini judul yang dipilih adalah "Faktor Faktor yang Berpengaruh terhadap gaya Kepemimpinan Kepala Kelurahan Duampanua Kecamatan Baranti kabupaten Sidrapdalam pelaksanaan manajemen pembangunan"

\section{Rumusan Masalah}

Rumusan masalah dalam penelitianini :"Faktor-faktor apa yang mempengaruhi gaya kepemimpinan Kepala Kelurahan Duampanua Kecamatan Baranti Kabupaten Sidrap dalam Melaksanakan Manajemen Pembangunan?

\section{METODE PENELITIAN.}

Penelitian ini menggunakan kombinasi pendekatan kuantitatif (metode survei) dan pendekatan kualitatif. Metode survei adalah metode yang mengambil contoh data dari satu populasi dan menggunakankuesioner sebagai alat pengumpulan data yang pokok 
(Misbahuddin, 2016). Dengan memadukan kedua pendekatan tersebut diharapkan upaya pemahaman gaya kepemimpinan dalam pengambilan keputusan, faktor-faktor yang mempengaruhi gaya kepemimpinan dalam pelaksanaan pembangunan pada Kelurahandapat dilakukan secara lebih komprehensif.

Pengumpulan data primer dan Data sekunder dapat berbentuk dokumen, laporan-laporan yang memuat data kualitatif dan laporan penelitian ataupun dalam bentuk lain berupa

Populasi penelitian ini adalah seluruh pegawai pada pada Kantor Kelurahan Duampanua Kecamatan Baranti kabupaten Sidrap sebanyak 17 orang dengan Jumlah Pegawai Negeri/ASN sebanyak 5 Orang dan Tenaga Sukarela Sebanyak 12 Orang. Pemilihan sampel menggunakan teknik Sampel Populasi yaitu dengan memilih langsung Semua Pegawai yang terlibat.

Untuk menganalisis data yang telah terkumpul, digunakan teknik analisis dengan menggunakan metode kualitatif deskriptif.

\section{HASIL PENELITIAN DAN PEMBAHASAN}

\section{Pengaruh Gaya Kepemimpinan Kepala Kelurahan Duampanua \\ Menurut Rivai (2004), Gaya} kepemimpinan Lurah sebagaimana telah dikemukakan pada definisi operasional dikategorikan menjadi empat gaya kepemimpinan, yaitu gaya kepemimpinanotoriter, gaya kepemimpinan patemalistik, gaya kepemimpinan demokratik,gaya kepemimpinan laissez faire serta gaya kepemimpinan kharismatik. Penerapan gaya kepemimpinan Lurah Duampanua Kecamatan Baranti Kabupaten Sidrap dikaji pada bidang atau lingkungan kegiatan pengambilan keputusan/pemecahan masalah berikut: kegiatan yang berkaitan dengan kesejahteraan pegawai, kegiatan yang berkaitan dengan pendelegasian tugas dari pemimpin (Lurah) kepada pegawai, kegiatan yang berkaitan dengan kinerja Pembangunan di lingkungan Kelurahan, serta kegiatan yang berkaitan dengan pemberian pelayanan Kelurahan.

\section{Kegiatan yang Berkaitan dengan Kesejahteraan Pegawai}

Pada pengambilan keputusan/pemecahan masalah yang dilakukan oleh Lurah berkaitan dengan kegiatan kesejahteraan pegawai, Lurah Duampanua terlihat menerapkan gaya kepemimpinan demokratik.

Table : 1. Tanggapan Responden Berkaitan Dengan Kesejahteraan Pegawai

\begin{tabular}{|c|l|c|c|}
\hline No & \multicolumn{1}{|c|}{ Kategori } & Frekuensi (F) & Presentase (\%) \\
\hline 1. & Sangat Baik & 10 & 59 \\
2. & cukup baik & 5 & 29 \\
3. & Kurang baik & 2 & 12 \\
4. & Tidak baik & 0 & 0 \\
\hline & Total & 17 & 100 \\
\hline
\end{tabular}

Sumber: Data Primer, 2019

Berdasarkan Tabel 1. di atas menunjukkan ada sebanyak 10 responden (59\%) yang memberikan jawaban tentangImplementasi Kepemimpinan Kepala Kelurahan Duampanua Berkaitan dengan Kesejahteraan Pegawai sangat baik dengan alasan Terhadap unsur ini menunjukkan bahwa pada umumnya responden menilai kesejahteraan pegawai cukup baik. sementara 2 responden (12\%) yang menyatakan kurang baik dengan alasan bahwa kepala kelurahan Duampanua belum sepenuhnya memperhatikan 
masalah kesejahteraan pegawai terbukti dari kebijakan yang dikeluarkan belum sepenuhnya mampu memberikan kesejahteraan kepada para Pegawai khususnya masalah yang berkaitan dengan kesejahteraan Pegawai, seperti permasalahan yang dihadapi Pegawai di dalam keluarganya meliputi kebutuhan hidupnya sehari-hari, ketercukupan sandang, pangan dan papan kebutuhan pegawai.

Penerapan gaya kepemimpinan Lurah dilakukan dalam berbagai penyelesaian kasus yang dihadapi Pegawai seperti masalah keluarga pegawai. Dalam hal tersebut, disetiap penyelesaian masalah, Lurah telah mampu menjalankan kepemimpinan yang baik. Hal tersebut diimplementasikan dengan kemampuan
Lurah dalam membaca situasi masalah yang dihadapi dan tahap selanjutnya Lurah menerapkan gaya kepemimpinan yang sesuai dengan situasi permasalahan tersebut.

\section{Kegiatan yang Berkaitan dengan Pendelegasian Tugas dari Pemimpin (Lurah) Kepada Pegawai}

Kegiatan pendelegasian tugas dari Lurah kepada pegawai merupakan salah satu kegiatan yang penting dan perlu dibahas untuk mengetahui serta memahami penerapan gaya kepemimpinanLurah dalam pengambilan keputusan/pemecahan masalah. Untuk lebih jelasnya dapat dilihat pada tabel berikut ini:

Table : 2. Tanggapan Responden Berkaitan dengan Pendelegasian Tugas dari Pemimpin (Lurah) Kepada Pegawai

\begin{tabular}{|c|l|c|c|}
\hline No & \multicolumn{1}{|c|}{ Kategori } & Frekuensi (F) & Presentase (\%) \\
\hline 1. & Sangat Baik & 7 & 41 \\
2. & Cukup baik & 9 & 53 \\
3. & Kurang baik & 1 & 6 \\
4. & Tidak baik & 0 & 0 \\
\hline & Total & 17 & 100 \\
\hline
\end{tabular}

Sumber: Data Primer, 2019

Dari tabel diatas Hal tersebut diimplementasikan dengan kemampuan Lurah dalam membaca situasi permasalahan yang dihadapi dan tahap selanjutnya Lurah menerapkan gaya kepemimpinan yang sesuai dengan situasi permasalahan tersebut. dan 9 responden (53\%), menyatakan cukup baik dengan alasan bahwa Lurah mampu menumbuhkan kerjasama diantara pegawai, dan begitu juga sebaliknya pegawai meyakini bahwa seorang Lurah mempunyai kemampuan untuk mengelola seluruh kegiatan Kelurahan berkaitan dengan tujuan, visi dan misi Kelurahan yang telah ditetapkan sementara 1 responden (6\%) menyatakan kurang baik dengan alasan bahwa dalam pendelegasian tugas kepada Pegawai Kepala Kelurahan hanya melibatkan orang tertentu saja yakni orang yang dianggap mampu menjalankan tugas tersebut tanpa memberi kesempatan kepada pegawai yang lain untuk belajar dan berproses.

Pada kegiatan ini, Lurah Duampanua terlihat menerapkan gayakepemimpinan Demokratik. menunjukkan bahwa gaya kepemimpinan Demokratik lebih dominan diterapkan Lurah dalam pengambilan keputusan/pemecahan masalah dibandingkan dengan gaya kepemimpinan yang lain.

Sehubungan dengan penerapan gaya kepemimpinan demoratik yang lebih dominan diterapkan Lurah dalam 
kegiatan pendelegasian tugas kepada pegawai. Seorang responden pegawai, A.J (50 tahun) menuturkan sebagai berikut:

"Dalam pengambilan keputusan/pemecahan masalah berkaitan pendelegasian tugas kepada pegawai, Lurah selalu mendiskusikan tugas yang akan diberikan kepada pegawai dan selalu memberikan arahan dan petunjuk terhadap pekerjaan tersebut. Jika di dalam pelaksanaannya terdapat masalah yang harus diputuskan, maka pegawai diajak berdiskusi tentang pekerjaan tersebut, setelah itu baru diambil keputusan terbaik oleh Lurah dengan mempertimbangkan saran/masukan dari pegawai."

Dari hal tersebut dapat diidentifikasi,proses pengambilan keputusan/pemecahan masalah, Lurah menerapkan gaya kepemimpinan konsultatif. Hal ini dicirikan dari pengambilan keputusan/pemecahan masalah dilakukan oleh pemimpin dengan terlebih dahulu mendengarkan berbagai masukan/saran dari para pegawainya dan pemimpin memberikan keleluasaan pegawai untuk melaksanakan pekerjaan.

Pendelegasian tugas dari Lurah kepada pegawai, di dalamnya terdapat dua garis yang membedakannya, yaitu garis komando dan garis koordinasi. Garis komando merupakan garis perintah pendelegasian tugas dari Lurah sebagai pemimpin terhadap pegawainya secara langsung. Sedangkan garis koordinasi adalah garis pendelegasian tugas yang mengharuskan para staf dan Kasi untuk mengkoordinasikan terlebih dahulu dalam menjalankan tugas Kelurahan. Dari kedua garis tersebut, pada intinya seluruh kegiatan Kelurahan dalam pendelegasian tugas dari Lurah terhadap pegawainya, Lurah bertanggung jawab penuh atas kegiatan Kelurahan. Hal ini diperkuat dengan struktur tugas yang jelas, yaitu adanya hierarki tugas dan tanggung jawab.

\section{Kegiatan yang Berkaitan dengan Pemberian Pelayanan Kelurahan}

Kegiatan pemberian pelayanan Kelurahan terhadap masyarakat merupakan salah satu kegiatan penting dan perlu dikaji untuk mengetahui penerapan gaya kepemimpinan Lurah dalam pengambilan keputusan/pemecahan masalah dapat dilihat pada tabel berikut ini :

Tabel : 3. Tanggapan Responden Berkaitan dengan Pemberian Pelayanan Kelurahan

\begin{tabular}{|c|l|c|c|}
\hline No & \multicolumn{1}{|c|}{ Kategori } & Frekuensi (F) & Presentase (\%) \\
\hline 1. & Sangat Baik & 2 & 12 \\
2. & Cukup baik & 9 & 53 \\
3. & Kurang baik & 5 & 29 \\
4. & Tidak baik & 1 & 6 \\
\hline & Total & 17 & 100 \\
\hline
\end{tabular}

Sumber: Data Primer, 2019

Hal ini berarti adanya kebebasan berpendapat dengan sikap penuh tanggung jawab yang diberikan Lurah kepada pegawai dalam memberikan saran/masukan terhadap kegiatan yang menyangkut pelayanan yang diberikan Kelurahan kepada masyarakat. Dengan gaya kepemimpinan tersebut, artinya
Lurah mampu menumbuhkan kerjasama diantara pegawai, dan begitu juga sebaliknya, pegawai meyakini bahwa Lurah mempunyai kemampuan untuk mengelola seluruh kegiatan Kelurahan berkaitan dengan tujuan, visi dan misi Kelurahan yang telah ditetapkan. dan 9 responden (53\%), menyatakan cukup 
baik dengan alasan bahwa Penerapan gaya kepemimpinan yang dominan demokratik tersebut, sejauh ini dapat menghasilkan pelayanan yang cukup memuaskan, khususnya bagi masyarakat yang menerima pelayanan dari pihak Kelurahan Sejauh ini pelayanan Kelurahan yang diberikan kepada masyarakat sudah cukup baik karena setiap pegawai telah bekerja dengan sebaik-baiknya disamping itu juga Kelurahan memiliki SDM yang bukan asal-asalan tetapi sudah terlatih. Sementara 5 responden (29 \%) menyatakan kurang baik dengan alasan bahwa untuk mengantisipasi dan menanggapi keluhan masyarakat terhadap pelayanan yang diberikan Kelurahan tersebut, penerapan gaya kepemimpinan Lurah yang demokratik, mengharuskan Lurah untuk selalu menampung masukan/saran yang diberikan masyarakat terhadap pelayanan Kelurahan sehingga membutuhkan waktu yang agak lama serta menghambat proses pelayanan, dan 1 responden $(6 \%)$ menyatakan tidak baik dengan alasan bahwa Hasil penelitian pada tabel tersebut di atas dapat memberikan informasi dari 17 responden yang memberikan jawaban terhadap pemberian pelayanan yang menyatakan sangt baik adalah 2 responden (12\%), dengan alasan bahwa Penerapan gaya kepemimpinan terhadap pemberian pelayanan yang demokratik didukung oleh sikap Lurah dalam pengambilan keputusan dan pemecahan masalah berkaitan dengan pelayanan Kelurahan dilakukan oleh pemimpin (Lurah) setelah mendengarkan masukan/sarandari pegawai. Dengan gaya kepemimpinan yang diterapkan Lurah dalam hal pelayanan Kelurahan kepada masyarakat. belum cukup baik. karena penerapan gaya kepemimpinan tersebut membuat keputusan-keputusan yang dihasilkan kurang cepat jika dilihat dari efisiensi waktu yang dibutuhkan. Ini bisa dilihat seringkali pegawai Kelurahan tidak ada di tempat saat warga ingin mengurus surat keterangan/identitas. Hal ini sejalan dengan pemikiranHandayaningrat, Suwarno. (2003).

Penerapan gaya kepemimpinan Lurah dalam berbagai penyelesaian permasalahan yang dihadapi pegawai dalam penyelesaian pekerjaan terhadap pelayanan yang diberikan kepada masyarakat, Lurah telah mampu menjalankan kepemimpinan yang baik. Hal tersebut diimplementasikan dengan kemampuan Lurah dalam membaca situasi permasalahan yang dihadapi dan tahap selanjutnya Lurah menerapkan gaya kepemimpinan yang sesuai dengan situasi permasalahan tersebut.

Gaya kepemimpinan yang dominan digunakan Lurah dalam proses pengambilan keputusan berkaitan dengan pelayanan Kelurahan adalah gaya kepemimpinan demokratis.Penerapan gaya kepemimpinan tersebut, telah mampu menghasilkan berbagai keputusan yang berguna berkaitan dengan pelayanan yang diberikan Kelurahan kepada masyarakat. Beberapa contoh pelayanan yang diberikan Kelurahan meliputi pembuatan surat pengantar $\mathrm{KTP} / \mathrm{KK}$ untuk Kecamatan, pencegaran dan penanggulanagan bencana alam serta pelayanan lainnya.

\section{Kegiatan berkaitan dengan Pelaksanaan Pembangunan}

Penerapan gaya kepemimpinan Lurah berkaitan dengan Pelaksanaan pembangunan sangatlah baik.mengingat pembangunan adalah merupakan sasaran yang perlu diperhatikan didalam menjalankan roda pemerintahan di kelurahan karena pembangunan adalah tolak ukur bagi keberhasilan seorang pemimpin.untuk lebih jelasnya dapat dilihat pada table berikut ini: 
Table : 4. Tanggapan Responden Berkaitan Dengan Pelaksanaan Pembangunan

\begin{tabular}{|c|l|c|c|}
\hline No & \multicolumn{1}{|c|}{ Kategori } & Frekuensi (F) & Presentase (\%) \\
\hline 1. & Sangat Baik & 6 & 35 \\
2. & Cukup baik & 9 & 53 \\
3. & Kurang baik & 2 & 12 \\
4. & Tidak baik & 0 & 0 \\
\hline & Total & 17 & 100 \\
\hline
\end{tabular}

Sumber: Data Primer, 2019

Hasil angket terhadap terhadap pelaksanaan pembangunan menunjukkan 6 responden $35 \quad(\%)$ menyatakan sangat baik dengan alasan bahwa Pada setiap pelaksanaan program pembangunan di lingkungan Kelurahan, pengambilan keputusan terhadap pemecahan masalah tersebut umumnya melibatkan para pegawai. Dari hal tersebut dapat diidentifikasi, pada proses pengambilan keputusan/pemecahan masalah, Lurah menerapkan gaya kepemimpinan demokratik. Hal ini dicirikan dari keikutsertaan Lurah dan pegawai dalam pengambilan keputusan/pemecahan masalah. Diikutsertakannya pegawai dalam pengambilan keputusan secara bersamasama, bertujuan agar keputusan yang dihasilkan dapat berjalan tepat, cepat dan akurat mengingat pelaksanaan pembangunan merupakan tujuan utama dan merupakan salah satu tolak ukur keberhasialan seorang pemimpin. Dan 9 responden $(53 \%)$ menyatakan cukup baik adalah yang paling banyak dengan indikator bahwa kegiatan berkaitan dengan pelaksanaan pembangunan yang terjadi di lingkungan Kelurahan, Lurah telah mampu menjalankan kepemimpinan yang baik. Hal tersebut diimplementasikan dengan kemampuan Lurah dalam membaca situasi permasalahan yang dihadapi dan tahap selanjutnya Lurah menerapkan gaya kepemimpinan yang sesuai dengan situasi permasalahan tersebut.Gaya kepemimpinan yang dominan digunakan Lurah dalam proses pengambilan keputusan berkaitan dengan pelaksanaan pembangunan di lingkungan Kelurahan adalah gaya kepemimpinan demokratik. Penerapan gaya kepemimpinan kepala kelurahan, telah mampu menghasilkan berbagai keputusan yang berguna berkaitan dengan pelaksanaan pembangunan di lingkungan Kelurahan Penerapan gaya kepemimpinan Lurah yang demokratik ini menekankan adanya persamaan antara pemimpin (Lurah) dengan para pegawainya, terutama berkaitan dengan pengambilan keputusan yang dilakukan dengan cara musyawarah untuk mengambil suatu keputusan. Sedangkan 2 responden $(12 \%)$ adalah yang paling sedikit menyatakan kurang baik adalah mereka yang kurang paham dengan tugas dan tanggung jawab yang telah diberikan oleh kepala kelurahan sehingga dalam pelaksanaanya pekerjaan itu diselesaikan asal-asalan tanpa perhitungan yang matang.

Penerapan gaya kepemimpinan demokratik lebih dominan diterapkan Lurah dalam kegiatan berkaitan dengan pelaksanaan pembangunan di lingkunganKelurahan, penerapan gaya kepemimpinan Lurah dalam berbagai penyelesaian permasalahan.

\section{Faktor-Faktor Yang Mempengaruhi Penerapan Gaya Kepemimpinan Lurah}

Penerapan gaya kepemimpinan Lurah yang terjadi di Kelurahan Duampanua dipengaruhi oleh berbagai faktor dalam hal ini akan ditinjau faktor pendukung dan faktor penghambat. 
Faktor pendukung

1. Pengalaman dan Latar Belakang Pendidikan

Pengalaman merupakan guru terbaik dalam kehidupan. Dengan pengalaman membuat individu menjadi lebih mengetahui terhadap sesuatu hal dan mendewasakan individu tersebut.

Tabel 5. Distribusi Responden berdasarkan tingkat Pengalaman Pegawai yang Bersangkutan

\begin{tabular}{|c|l|c|c|}
\hline No & \multicolumn{1}{|c|}{ Kategori } & Frekuensi (F) & Presentase (\%) \\
\hline 1. & Sangat Sesuai & 3 & 18 \\
2. & Sesuai & 9 & 53 \\
3. & Kadang-kadang Sesuai & 5 & 29 \\
4. & Tidak Sesuai & 0 & 0 \\
\hline & Total & 17 & 100 \\
\hline
\end{tabular}

Sumber: Data Primer, 2019

Hasil angket terhadap tingkat pengalamanmenunjukkan 3 responden (18) \% menyatakan sangat sesuai dengan alasan bahwa pengalaman merupakan salah satu faktor penunjang yang dapat memudahkan dalam penyelesaiansetiap

tugas dan tanggung jawab. pengalaman yang dimiliki pemimpin,memberikan pengetahuan kepadanya yang selanjutnya dapat mempengaruhi pola tindak pemimpin.

Table : 6. Jumlah Pegawai Berdasarkan Latar Belakang Pendidikan

\begin{tabular}{|c|l|c|c|}
\hline No & \multicolumn{1}{|c|}{ Kategori } & Frekuensi (F) & Presentase (\%) \\
\hline 1. & Sarjana (S1) & 2 & 18 \\
2. & SMA & 12 & 71 \\
3. & SMP & 3 & 12 \\
\hline & Total & 17 & 100 \\
\hline
\end{tabular}

Sumber data primer, 2019

Berdasarkan tabel di atas menunjukkan ada sebanyak 2 orang (18\%) pegawai yang memiliki tingkat pendidikan Sarjana (S1). Tingkat pendidikan tersebut tampak berpengaruh dalam pengambilan keputusan yang dilakukan Lurah. Sementara 12 orang (71 \%) yang memiliki tingkat pendidikan (SMA) dan 3 orang (12\%) yang tingkat pedidikan (SMP).

Disamping pengalaman,latar belakang pendidikan adalah merupakan faktor yang sangat menentukan keberhasilan dalam pelaksanaan roda
pemerintahan.Terutama dari segi pelayanan. Secara logis,pegawai yang mempunyai latar pendidikan yang rendah akan sangat berpengaruh pada kemampuan kerja pegawai tesebut. Utamanya dari segi penerapan peraturan dan perundang-undangan sehingga dalam memberikan pelayanan kepada masyarakat dapat dilakukan sesuai peraturan dan perundang-undangan yang mengaturnya dan ketika seorang pegawai mempunyai latar belakang pendidikan yang tinggi 
akan sangat mendukung setiap pekerjaan yang dihadapinya.

\section{Motivasi}

Motivasi adalah pemberian daya penggerak yang menciptakan kegiatan agar mampu bekerja sama dengan segala daya upaya untuk mencapai kepuasan bersama.

Tabel 7. Distribusi Responden Berkaitan Dengan Motivasi kerja

\begin{tabular}{|c|l|c|c|}
\hline No. & \multicolumn{1}{|c|}{ Kategori } & Frekuensi (F) & Presentase (\%) \\
\hline 1. & Selalu Memberi Petunjuk & 3 & 18 \\
2. & Cukup Memberi Petunjuk & 9 & 53 \\
3. & Kadang-Kadang & 5 & 29 \\
4. & Tidak Pernah & 0 & 0 \\
\hline & Total & 17 & 100 \\
\hline
\end{tabular}

Sumber: Data Primer, 2019

Berdasarkan table 7 tersebut, 3 responden $18 \%$ menyatakan motivasi kerja Kepala Kelurahan sangat baik dengan alasan untuk memiliki pengaruh terhadap gaya kepemimpinan, pendidikan saja tidak menjadi patokan dalam pengambilan keputusan. yang penting. Hal ini dapat berakibat dalam pengambilan keputusan/pemecahan masalah yang dihadapi Kelurahan yang hampir selalu dapat diatasi secara

Tabel 8. Distribusi Responden Berkaitan Dengan Motivasi kerja

\begin{tabular}{|c|l|c|c|}
\hline No & \multicolumn{1}{|c|}{ Kategori } & Frekuensi (F) & Presentase (\%) \\
\hline 1. & Semangat Sekali & 2 & 18 \\
2. & Kurang Semangat & 12 & 71 \\
3. & Kadang-Kadang Semangat & 3 & 12 \\
4. & Tidak Pernah Semangat & 0 & 0 \\
\hline & Total & 17 & 100 \\
\hline
\end{tabular}

Sumber: Data Primer, 2019

Berdasarkan tabel tersebut diatas 2 responden $18 \%$ menyatakan mereka memiliki semangat yang tinggi dan 12 responden $71 \%$ yang menyatakan cukup semangat dan 3 responden $12 \%$ dan tidak ada responden yang tidak pemah semangat didalam melakukan pekerjaanya.

Bahwa berdasarkan table diatas cukup memberikan alasan bahwa faktor atau aspek yang tidak cepat dan tepat. Sementara itu 5 responden $29 \%$ menyatakan kurang baik dengan alasan bahwa menurunnya kinerja pegawai disebabkan oleh kurangnya motivasi kepala kelurahan baik kepada diri sendiri maupun kepada para pegawai sehingga kerja sama dan kekompakan diantara sesama rekan kerja tidak berjalan maksimal. 
yang memiliki motivasi kerja yang rendah tidak dapat secara maksimal melaksanakan tugasnya dan akibatnya adalah kemampuan kerja yang rendahdan hal ini sangat mempenganuhi kualitas kerja aparat kelurahan secara keseluruhan rendahnya motivasi kerja aparat,dapat dilihat dari pelaksanaan tugas oleh para aparat tersebut,dimana banyak sekali pekerjaan yang sengaja ditunda penyelesaianya.

Salah satu hal yang dapat mendukung peningkatan kemampuan kerja aparat adalah meningkatnya motivasi aparat, baik itu motivasi diri sendiri maupun motivasi dari pimpinan itu sendiri dan keduanya sangat dibutuhkan untuk dimiliki.Oleh karena itu,diharapkan agar motivasi kerja aparat dapat meningkat sehingga dalam melaksanakan pekerjaanya dapat bertindak secara ikhlas dengan penuh rasa tanggung jawab tentunya bahwa untuk meningkatkanmotivasi kerja aparat,dituntut keterlibatanpimpinan untuk menciptakan suasana kerja yang harmonis dengan tetap memperhatikan prinsipprinsip kepegawaian.

3. Disiplin Pegawai

Tabel 9. Distribusi Responden berdasarkan tingkat disiplin Menurut Kinerja Pegawai yang Bersangkutan

\begin{tabular}{|c|l|c|c|}
\hline No & \multicolumn{1}{|c|}{ Kategori } & Frekuensi (F) & Presentase (\%) \\
\hline 1. & Tepat Waktu & 3 & 18 \\
2. & Selalu & 9 & 53 \\
3. & Kadang-kadang & 5 & 29 \\
4. & Tidak Pernah & 0 & 0 \\
\hline & Total & 17 & 100 \\
\hline
\end{tabular}

Sumber: Data Primer, 2019

Dari tabel 9 tersebut,tampak bahwa $53 \%$ responden pegawai termasuk dalam kategori tingkat disiplin cukup baik. Sementara itu, $18 \%$ responden pegawai lainnya termasuk dalam kategori disiplin sangat baik dan $29 \%$ diantaranya dalam kategori kurang baik.

Secara keseluruhan dapat dinyatakan bahwa kinerja pegawai Kelurahan Duampanua tergolong kinerja cukup tinggi. Pada penilaian kedisiplinan dan hasil kerja pegawai, dari 17 responden 3 orang pegawai menyatakan tepat waktu tiba dikantor sementara 9 orang menyatakan selalu tepat waktu dan 5 orang menyatakan kadangkadang tepat waktu tiba dikantor. Sehubungan dengan hal ini, salah seorang responden pegawai (SN, 40 tahun) mengemukakan: "Dalam hal menjalankan tugas sesuai dengan pekerjaan, saya selalu tepat waktu dan teliti. Hal ini mengingat setiap pegawai pernah dan selalu dituntut untuk menyelesaikan tugas seharihari dengan cepat dan baik oleh pemimpin (Lurah).".

Hal tersebut mengindikasikanbahwa kedisiplinan pegawai Kelurahan Duampanua secara umum cukup baik, sebagaimana diungkapkan sebelumnya oleh Lurah Duampanua. Bahwa di satu sisi ada pegawai yang dalam melaksanakan tugasnya dilakukan secara segera, disisi lain terdapat juga pegawai yang ketika menjalankan tugas dengan santai. Jika dikaitkan ke masa lalu, hal tersebut terjadi karena kebiasaaan gaya lama yang dilakukan pegawai 
ketika Kelurahan belum terbentuk secara resmi, tetapi masih berstatus sebagai Kelurahan persiapan dan status kepegawaiannyapun masih sebagai staf sukarela, bukan sebagai Pegawai Negeri Sipil (PNS) ataupun Tenaga Kerja Kontrak (TKK).

\section{Faktor Penghambat}

1. Karakteristik Pegawai

Faktor

Penerapangaya kepemimpinan Lurah Duampanua dipengaruhi oleh karakteristik pegawai. Pada Kelurahan
Duampanua, tingkat pendidikan sangat beragam sebagian besar pegawai merupakan lulusan Sekolah Menengah Atas (SMA), di samping lainnya berpendidikan Sekolah Menengah Pertama (SMP). Dan hanya dua orang diantaranya yang merupakan lulusan Sarjan (S1) Adanya perbedaan dalam hal pendidikan dapat mempengaruhi kemampuan pegawai dalam bekerja, sehingga antara satu dengan pegawai yang lain memiliki motivasi kerja yang berbeda.

Table : 10. Tanggapan Responden Berkaitan Dengan Karakteristik Pegawai

\begin{tabular}{|c|l|c|c|}
\hline No & \multicolumn{1}{|c|}{ Kategori } & Frekuensi (F) & Presentase (\%) \\
\hline 1. & Sangat Bertanggung Jawab & 2 & 12 \\
2. & Bertanggung Jawab & 9 & 53 \\
3. & Kurang Bertanggung Jawab & 5 & 29 \\
4. & Tidak Bertanggung Jawab & 1 & 6 \\
\hline & Total & 17 & 100 \\
\hline
\end{tabular}

Sumber: Data Primer, 2019

Dari tabel diatas menunjukkan dari 17 responden 2 orang (12\%) menyatakan sangat bertanggung jawab dalam mengerjakan tugas-tugas yang telah diberikan oleh atasan dan mampu diselesaikan dengan baik. Sementara 9 orang $(53 \%)$ yang menyatakan bertanggung jawab dengan alasan bahwa meskipun tugas yang diberikan oleh atasan itu sangat sulit tapi dengan semangat dan integritas yang tinggi setiap pekerjaan dapat diselebasaikan tepat waktu

Hal ini menyebabkan penerapangaya kepemimpinan yang diterapkan Lurah Duampanua selalu mempertimbangkan karakteristik pegawai. ini tercermin dalam pemberian tugas-tugas yang diberikan Lurah kepada pegawai selalu disertai bimbingan dan arahan dari pemimpin (Lurah).

2. Lingkungan Organisasi
Situasi merupakan salah satu faktor yang mempenganuhi penerapangaya kepemimpinan dalam pengambilan keputusan. Situasi tersebut dapat meliputi situasi atau keadaan lingkungan kerja serta situasi masalah yang mempengaruhi pemimpin dalam pengambilan keputusan. Kedua aspek tersebut sangatlah berpengaruh sebagai faktor yang mempengaruhi dalam pengambilan keputusan pemimpin. Lingkungan atau kondisi kerja di lingkungan organisasi Kelurahan Duampanua mempengaruhi penerapan gaya kepemimpinan yang diterapkan pemimpin (Lurah) (Robbin 2006). Pada suatu situasi kerja tertentu, Lurah Duampanua menerapkan gaya kepemimpinann demokratik. Pada situasi yang lain, Lurah menerapkan gaya kepemimpinan otoriter, 
paternalistik ataupun laissez faire. Hal tersebut antara lain dikemukakan oleh H.R (50 tahun) yang menyatakan: "Pada suasana atau iklim kerja serta suasana organisasi secara keselunuhan pasti memiliki pengaruh terhadap gaya kepemimpinan yang diterapkan.

Tabel 11. Distribusi Responden Mengenai Pengaruh Lingkungan Organisasi Terhadap Kekompakan Pegawai Dalam Bekerja.

\begin{tabular}{|c|l|c|c|}
\hline No & \multicolumn{1}{|c|}{ Kategori } & Frekuensi (F) & Presentase (\%) \\
\hline 1. & Sangat Kompak & 3 & 18 \\
2. & Kadang-Kadang & 9 & 53 \\
3. & Kurang Kompak & 5 & 29 \\
4. & Tidak Kompak & 0 & 0 \\
\hline & Total & 17 & 100 \\
\hline
\end{tabular}

Sumber: Data Primer, 2019

Dari hasil tabel tersebut diatas menunjukkan 3 responden (18) menyatakan para pegawai sangat kompak dalam bekerja karena suasana lingkungan kerja yang penuh dengan suasana kekeluargaan, sehingga dapat menciptakan suasana kerja yang nyaman dan lingkungan harmonis diantara pegawai dan pemimpin. Dan 9 responden $(53 \%)$ yang menyatakan kadang-kadang dengan alasan bahwa ada kalanya pegawai dalam menyelesaikan pekerjaanya tidak memperlihatkan kerja sama yang baik hal ini menyebabkan suasana kerja dalam kantor tidak kondusif.

\section{KESIMPULAN}

Berdasarkan hasil Penelitian dan analisis yang telah dilakukan, dapat dikemukakan beberapa butir pokok kesimpulan sebagai berikut.

1. Gaya kepemimpinan yang dominan digunakan Lurah berkaitan dengan kegiatan di Kelurahan Alewanuae adalah gaya kepemimpian demokratik, dan kemudian menyusul gaya kepemimpinanpatemalistik. Pada kegiatankegiatan tertentu juga diterapkan gaya kepemimpinan otoriter dan gaya kepemimpinan laissez faire. Penerapangaya kepemimpinan Lurah yang terutama gaya kepemimpinan demokratik dan gaya kepemimpinan paternalistik memberikan pengaruh terhadap kinerja pegawai Kelurahan berkaitandengan berbagai kegiatan Kelurahan.

2. Faktor-faktor pendukung penerapan gaya kepemimpinan Lurah adalah: (1) pengalaman pemimpin dalam hal ini meliputi latar belakang pendidikan yang dimiliki oleh pemimpin, kepribadian pemimpin, serta nilai-nilai yang dianut pemimpin, (2) motivasi kerja pegawai (3) disipln keja pegawai terhadap pekerjaannya dan, kinerja pegawai Kelurahan Duampanua dalam mengerjakan pekerjaannya tergolong cukup tinggi. Sejumlah 75 persen pegawai berkinerja tinggi dan sisanya berkinerjasedang. Faktor penghambat penerapan gaya kepemimpinan Lurah adalah : Karasteristik pegawai, Lingkungan organisasi.

\section{SARAN}

Berdasarkan hasil penelitian dan kesimpulan yang telah dikemukakan, untuk lebih meningkatkan kinerja pegawai pada masa mendatang guna mengoptimalkan kinerja Kelurahan, maka sebaiknya : 
1. Lurah sebagai pemimpin Kelurahan menetapkan sanksi yang tegas terhadap pegawai yang melanggar peraturan kerja serta pentingnya penghargaan atas prestasi kerja yang dicapai agar pegawai tetap memiliki semangat kerja yang tinggi.

2. Pegawai dan juga warga masyarakat diberikan kesempatan yang lebih luas untuk menyampaikan ide atau saran yang membangun demi kemajuan Kelurahan.

\section{DAFTAR PUSTAKA}

GR. Terry, (1970) Azas - azas Manajemen, Terjemahan, Alumni Bandung, ,
Siagian, Sondang P., (1997), Manajemen Sumber Daya Manusia, Jakarta: Bumi Aksara

Handayaningrat, Suwarno. (2003). Administrasi Pemerintahan Dalam Pembangunan Nasional. Jakarta: PT.Gunung Agung.

Misbahuddin, 2016, Metode dan Teknik Penyunan laporan Penelitian, Badan Penerbit UNM Makassar,

Rivai, Veithzal. 2004. Manajemen Sumber Daya Manusia untuk Perusahaan. Penerbit PT. Raja Grafindo Persada:Jakarta.

Robbins Stephen P. (2006). Prinsipprinsip Perilaku Organisasi. Edisi 5. Jakarta: Erlangga. 